\title{
Three Authors of the Taisei Sankei
}

\author{
Morimoto Mitsuo
}

\begin{abstract}
The Taisei Sankei(大成算経 in Japanese) or the Dacheng Suanjing(in Chinese) is a book of mathematics written by Seki Takakazu 関孝和, Takebe Kataakira 建部賢明 and Takebe Katahiro 建部賢弘. The title can be rendered into English as the Great Accomplishment of Mathematics. This book can be considered as one of the main achievements of the Japanese traditional mathematics, wasan, of the early 18th century. The compilation took 28 years, started in 1683 and completed in 1711 . The aim of the book was to expose systematically all the mathematics known to them together with their own mathematics. It is a monumental book of wasan of the Edo Period (1603-1868). The book is of 20 volumes with front matter called Introduction and altogether has about 900 sheets. It was written in classical Chinese, which was a formal and academic language in feudal Japan. In this lecture we would like to introduce the wasan as expressed in the Taisei Sankei and three authors of the book. The plan of the paper is as follows: first, the Japanese mathematics in the Edo Period was stemmed from Chinese mathematics, e.g., the Introduction to Mathematics (1299); second, three eminent mathematicians were named as the authors of the Taisei Sankei according to the Biography of the Takebe Family; third, contents of the book showed the variety of mathematics which they considered important; fourth, the book was not printed but several manuscripts have been made and conserved in Japanese libraries; and finally, we show a tentative translation of parts of the text into English to show the organization of the encyclopedic book.
\end{abstract}

Keywords: wasan, Taisei Sankei(Dacheng Suanjing, the Great Accomplishment of Mathematics), Seki Takakazu, Takebe Kataakira, Takebe Katahiro; 和算, 大成算経， 関孝和, 建部賢明, 建部賢弘.

MSC: 01A25, 01A35, 01A50, 11-03, 11A63, 12E12

\section{Introduction of Mathematics}

One Chinese book of mathematics called the Suanxue Qimeng 算学啓蒙 (Sangaku Keimō in Japanese, Introduction to Mathematics in English) was written by Zhu Shijie 朱世傑 in 1299 during the Yuan dynasty. This book is a systematic textbook of traditional elementary mathematics and explains the theory of celestial element,

A part of this paper was read at the second International Conference on the History of Modern Mahtematics, May 17-20, 2012, Xi'an China, and at History and Pedagogy of Mathematics 2012, July 16-20, DCC, Daejeon, Korea.

Receiveded on Sep. 20, 2012, revised on Oct. 12, 2012, accepted on Oct. 22, 2012. 
tianyuanshu 天元術, which amounts to the theory of polynomials and algebraic equations of one variable in modern mathematics. It disappeared in China during the Ming dynasty but conserved and reprinted several times in years of King Sejong the Great in Korea. After the Japanese invations to Korea between 1592 and 1598, a copy of the Suanxue Qimeng was transfered to Japan. see for example [1]. The book was reprinted in 1658 by Hisada Gentetsu, and in 1672 by Hoshino Sanenobu with simple commentary see [6].

In 1690, Takebe Katahiro published the Accomplished Vernacular Commentary on the Suanxue Qimeng 算学啓蒙浐解大成. Takebe's commentary was written in colloquial Japanese and explained every detail of Chinese traditional mathematics including the tianyuanshu, and became one of the fundamental books for Japanese mathematicians. Takebe's master Seki Takakazu improved the tianyuanshu to be able to handle polynomials of several variables and invented the theory of elimination of variables in a system of algebraic equations. Seki's theory of elimination can be found in Volume 17 of the Taisei Sankei.

One of the common interests of Japanese mathematicians were the calculation of the circular rate $\pi$ in several digits, which was done with a method of acceleration of a sequence as shown in Volume 12 of the Taisei Sankei. This investigation eventually led to the discovery of the Taylor expansion formula of an inverse trigonometric function by Takebe Katahiro see [4, 5].

\section{Three authors}

No name of authors is written in the Taisei Sankei. We know the authors according to the Biography of the Takebe see [3, p. 270] written by Takebe Kataakira. We present here a tentative English translation :

.. 1) Although there have been plenty of books of mathematics in Japan and China, it is regrettable that the explanation of series of operations has not been done thoroughly. Thus three gentlemen, under the leadership of Katahiro, consulted and started in summer of the third year of Ten'a Period (1683) the compilation of a book to describe all the details of the exquisite theory newly invented, and expose all the theories descended from antiquity. The compilation lasted until the middle of Gen-

1) 少年(十六歳)より其の弟賢弘と相共に数学に参し、甚だ此の芸に志し有りて異国本朝の算書を披 きて、其の旨を暁にすといえども、解難の理会を以て得る事無し。于時関新助孝和(甲府相公綱重卿 の家臣) が算数世に傑出せりと聞きて、兄弟各々是を師として学ぶに、暦法天文同じく心を留めて、 昼夜寝食を忘れて巧夫をなし、共に術理貫通の道を深く発明す。蓋し、孝和が数に於いて禀( う) くる処生知安行( せいちあんこう)なり。賢弘も又太(はなはだ) 㕡智にして是に亜(つ)げり。 
roku Period (around 1695) ${ }^{2)}$. A book of 12 volumes in total was named the Sanpō Taisei, the Accomplished Mathematics. When it was almost copied, he [Katahiro] became a busy officer of the government and could not engage in the research of delicate mathematics, and Takakazu, being senile and sick for many years, could not think, examine and do research seriously ${ }^{3}$.

Therefore, from winter of the 14 th year of the same period (1701), while I engaged in the govenmental duties, I, Kataakira, worked on the book concentrating my own thinking for ten years, generalized ideas and wrote them in details into 20 volumes, and named the book the Taisei Sankei, of which I myself made a fair copy for completion ${ }^{4}$. (The compilation of this book started in Ten'a Period and completed at the end of Hōei Period (1711). Each volume was revised several ten times. Because of this elaboration, all of the compilation took 28 years to complete.) ${ }^{5)}$ Nevertheless, as I have tendency to indulge in seclusion, I do not like to become famous. As I have intention to remain incognito and hide my achievements, I handed over all my merits to Katahiro and professed to be a lunatic ${ }^{6)}$.

According to this information, the Taisei Sankei was edited by three gentlemen: Seki Takakazu 関孝和(1642?-1708), Takebe Kataakira 建部賢明 (1661-1716) and Takebe Katahiro 建部賢弘(1664-1739). Seki was a founder of Japanese traditional mathematics, wasan, and the Takebe brothers (Kataakira and Katahiro) were students of Seki.

The compilation started in 1683 on the initiative of Takebe Katahiro. The authors intended to present systematically all Japanese and Chinese mathematics known to them, and furthermore new theories inaugurated by Seki Takakazu, e.g., theory of resultants and determinants.

An interim version of twelve volumes was prepared around 1695, which was called the Sanpō Taisei (算法大成 Accomplished Mathematics), which was lost. At the final stage of compilation of this interim version, Seki Takakazu was senile and Katahiro was busy as government officer, Katahiro's elder brother Kataakira took care of the

2) 凡兴、倭漢の数学、其の書最も多しといえども、未だ釈鎖の奥妙を尽くさざることを嘆き、 [ 関孝和、 建部賢明、建部賢弘の] 三士相議して天和三年 [ 1683 ] の夏より賢弘其の首領と成りて各々新に考元得 る所の妙旨を悉く著し、就て古今の遺法を尽くして、元禄の中年 [1695年頃]に至りて編集す。

3) 総十二巻、算法大成と号して、粗是を書写せしに、[ 賢弘は] 事務の繁き吏と成され、自ら其の微を窮す ることを得ず。孝和も又老年の上、爾歳病患に逼られて考検熟思すること能わず。

4) 是に於て同十四年 [ 1701 ] の冬より賢明官吏の暇に躬ら其の思いを精すること一十年、広く考え詳に 註して二十巻と作し、更に大成算経と号して、手親ら草書し畢れり。

5) (此の書、天和の季に創りて宝永の末 $[$ 宝永八、1711 ] に終わる。毎一篇校訂すること数十度なり。 此の功を積むに因て総て二十八年の星霜を経畢んぬ。)

6) 然れ共、元来隠逸独楽の機ある故、吾が身の世に鳴ることを好まず。名を包み徳を隱すを以て本意と する者なれば、吾が功悉く賢弘に譲りて自ら癡人と称す。 
task, generalized description of mathematics, enlarged the book into 20 volumes and completed the compilation alone in 1711. The compilation took 28 years in total.

\section{Contents}

The Taisei Sankei has an independent front matter called Introduction and 20 volumes are divided into three parts: Introduction 首篇, Part A 前篇 (Volumes 1-3), Part B 中篇 (Volumes 4-15), and Part C 後篇 (Volumes 16-20).

Some manuscripts contain the General Catalogue, which lists up all volumes and chapters.

Introduction It includes Discussion on Mathematics and Numbers 算数論, Basic Numbers 基数, Large Numbers 大数, Small Numbers 小数, Degree 度数, Quantity 量数, Weight 衡数, Time 鈔数, Counting Board 縦横, Red and Black Counting Rods 正負, Operation on Counting Board 上退, and Terminologies 用字例.

Part A It treats elementary arithmetic ending with the introduction of determinants.

Volume 1 is entitled Five Techniques 五技 and treats Addition 加, Subtraction 減， Multiplication 因乗, Division 帰徐, and Extraction of Root 開方;

Volume 2 is entitled Miscellaneous Techniques 雑技 and treats Addition and Subtraction 加減, Multiplication and Division 乗除, and Extraction of Root 開方;

Volume 3 is entitled Various Techniques 変技 and treats advanced aspects of the content of the previous volumes, e.g., discriminant of algebraic equation of degree $2,3,4$, and 5 .

Part B Volume 4 serves as an introduction to Part B, which are further divided into two parts: Methods of Symbols 象法 (volumes 5-10) and Methods of Figures 形法 (volumes 11-15). The former treats traditional mathematics and games, and the latter treats various problems on geometry and measurement.

Volume 4 is named Three Essentials 三要 and includes Symbol and Figure 象形, Flow and Ebb 満干, and Numbers 数;

Symbol and Figure are the classification of mathematical objects and hence, problems. Volume 4 defines the structure of Part B.

Methods of Symbols Volume 5 treats Mutual Multiplication 互乗, Repeated Multiplication 畳乗, and Pile sums 垛積; 
Volume 6 treats Fractions 之分, Several Methods of fractions 諸約, and Art of Cutting Bamboo 翦管;

Volume 7 treats Magic Squares, Magic Circles 聚数, Josephus Problems 計子, 算 脱, and Coding Problems 験符;

Volumes 8 and 9 treat Daily Mathematics 日用術.

Methods of Figures Volume 10 treats Regular Squares 方, Rectangles 直, Regular Triangles 勾股, and Polygons 斜 (三斜、四斜、五斜);

Volume 11 discusses Regular Polygons 角法;

Volume 12 is concerned with Rates of Figure 形率, i.e., Circle Theory 円理, and treats the length of the circular circumstance 円率, the length of an arc 弧率, the volume of a ball 立円率, and the volume of spherical figures 球閶率.

Volume 13 is the same as Seki's monograph the Measurement 求積.

Volumes 14 and 15 are concerned with Techniques of Figure 形巧.

Part C It is composed of the last 5 volumes and treats Seki's theory of equations.

Volume 16 is named Discussion on Problems and Procedures 題術辨 and the same as Seki's Critical Studies of Problems 題術辨議之法.

Volume 17 is named Solutions of Well-posed Problems 全題解 and similar to Seki's Trilogy 三部抄, which contains Explicit Problems (i.e., direct calculation) 見 題, Implicit Problems (i.e., equation of one variable) 隠題, Concealed Problems (i.e., equation of several variables) 伏題, and Submerged Problems (i.e., non algebraic equations) 潜題.

Volume 18 is similar to Seki's Restoration of Defective Problems 病題擬;

Volumes 19 and 20 are named Examples of Operations 演段例 and contain 23 examples of algebraic equations.

\section{More than 20 Manuscripts}

The Taisei Sankei was never published but at least 20 manuscripts have been kept in Japanese libraries. See [2]. We cite here some of them:

1 MSS Kashū: University Tokyo Library, T20/29, 34, $61 \sim$ 73, 75.

2 MSS Kyoto A: Kyoto University, 219316.

3 MSS Kyoto B: Kyoto University, 102021.

4 MSS Kanō A: Kanō Collection, 7-31453.

5 MSS Kanō B: Kanō Collection, 7-20820.

6 MSS Okamoto: Okamoto Collection, 41-16964.

7 MSS Fujiwara: Fujiwara Collection, 450. 


\section{MSS Daté: Daté Collection.}

1. MSS Kashū was copied by a Confucian scholar Sakakibara Kashū while Takebe Katahiro was alive, and kept at his hand. There is no Introduction, and all volumes lack the name Taisei Sankei. It looks like a collection of independent booklets. Many scholars assume that MSS Kashū represents an early stage of the Taisei Sankei.

2 and 3. MSS Kyoto A and B are at Department of Mathematics. Both are available in color on the web page of the Kyoto University Library Network. As the red counting rods means positive numbers and the black negative, we cannot distinguish them in black and white picture. MSS Kyoto B was copied in 1851 and revised in 1853.

4, 5, 6, and 7. Four MSS 4-7 are conserved at Tohoku University Library and available in black and white on the web page of Tohoku University Library.

8. MSS Daté belonged to the Daté family. It is now conserved at Miyagi Prefectural Library and has been published in Volume 4 of the book [8]. The MSS Daté was copied by a mathematician Toita Yasusuke in 1780 and lacks Volume 20.

\section{Structure of the Taisei Sankei}

Along with the tradition of Chinese mathematics, Takebe Katahiro recognized mathematics as a bunch of mathematical problems. He tried to classify mathematics (i.e., mathematical problems) and to organize the Complete Book of Mathematics.

The general framework of the Taisei Sankei is stated at "Discussion on Mathematics and Numbers" in Introduction.

Volume 4 "Three Essentials" can be considered as the classification of all mathematical objects, thus giving a framework of known problems of mathematics treated in Part B.

Part C treats Seki's theory of algebraic equations, which was outlined in the "discussion on Problems and Procedures" (Volume 16). Note that not only well-posed problems but defect or incomplete problems are under consideration.

\subsection{Discussion on Mathematics and Numbers}

Here is a tentative translation of the text into English:

Mathematics is the Number. The Number describes the essence of the original property of all things; Mathematics describes everything already clarified and is employed for application. Certainly Chaos is originally "No Ultimate" but "Great Ultimate", which is the commencement 
of all Reasons. It moves and does generate One. ${ }^{7)}$

One is yang and odd. Here the emergence of the number is recognized as Increase, and as Flow. If discussed by Reason, it is the positive; if named by Substance, it is the symbol; if said by Technique, it is the addition. Number One becomes stable and generates Number Two. ${ }^{8)}$

Two is yin, and even. Here the generation of the number is recognized as Decrease, and as Ebb. If discussed by Reason, it is the negative; if named by Substance, it is the figure; if said by Technique, it is the subtraction. ${ }^{9)}$

In this way, two kinds of number, odd and even, are generated; the increase and the decrease, the Flow and the Ebb are named; two Reasons, positive and negative, are equipped; two Substances, the symbol and the figure, are distinguished; two Techniques, the addition and the subtraction, are prepared. They influence each other and accumulate numbers, where the names of large and small numbers are classified. ${ }^{10)}$

Here the repeated addition and subtraction are not fast in calculation. Therefore, create the multiplication table "nine times nine", and establish the method of ordering and shifting numbers.

By these methods two techniques [i.e., addition and subtraction] directly attain the number and quickly determine its order. ${ }^{11)}$

Repeated addition is called multiplication; repeated subtraction is called division, so-called the quotient-division method, the operation of which is difficult to understand easily. Therefore, compose the chant of division to replace it. The repeated division is called the root extraction. These [addition, subtraction, multiplication, division, and root extraction] are called "Five Techniques."12)

Further, classify the symbol and the figure into four forms, establish three levels of the flow and ebb, and distinguish numbers in four kinds. Apply them to each other. These [symbol and figure, flow and ebb, and number] are so called "Three Essentials."13)

Afterwards, as the condition becomes elaborated and the techniques

7) 算者数也。数言万物本具之体。算言已顕而相為之用也。蓋混沌本無極而太極, 是衆理之肇, 動而生一 焉。

8) 一者陽也、奇也。是数所始為増、為満。由理論之, 則為正; 由物名之, 則為象 ; 由技言之, 則為加也。 一数静而生二焉。

9) 二者陰也、偶也。是数所成為損、為干。由理論之, 則為負 ; 由物名之, 則為形; 由技言之, 則 [為]減也。

10) 既而奇偶両数相生, 增損満干名立, 正負二理相具, 象形二物相分, 加減両技相備, 則自是交感積数而 分大小之名義焉。

11) 是累加減者, 以功不速, 故創造九九合数, 立定位渉降法焉。両技由此, 直得其数, 速定其位矣。

12) 乃累加者, 号乗; 累減者, 号除; 是所謂商除也。然以其所為輯難暁, 故制帰除句訣而代之。累商如者 号開法。謂之五技。

13) 又分象形四体,立満干三科, 別数四等, 而互相為用。謂之三要。 
are applied in varied way, problems are established and procedures of solution developed. These [problem and procedure] are called the "Two Significances." ${ }^{\prime 14)}$

In this way, [the book] is equipped with the formula of five techniques, explains the methods of symbols and figures, analyze problems precise or not, and distinguish procedures good or bad. These altogether, with their variations, exhaust the way of mathematics fully. Therefore, I edit an article of summary, place it at the beginning of the book of 20 volumes to write the outline of the organization of the book for the reference of the reader. ${ }^{15)}$

\subsection{Three Essentials}

Volume 4 was named Three Essentials 三要, in which Takebe Katahiro's philosophy on mathematics was exposed. Volume 4 is divided into three sections: Symbols and Figures 象形; Flow and Ebb 満干; and Numbers 数. Each section starts with a general statement followed by problems (67 in total) which serve as examples for the general statement.

In 2010, we already discussed Volume 4 in an international conference in Xi'an see [7] and we refrain from discussing it again.

\subsection{Discussion on Problems and Procedures}

Part C treats Two Evidences, i.e., problem and procedure.

Volume 16 starts with the following statement

The problem is to write the condition on symbol and figure and to question the number hidden in it. Therefore, the condition is for the problem and can be changed properly. ${ }^{16)}$

If the number originally equipped is clarified and stated, the condition is right; If it is stated with many techniques, the condition is changeable. If the statement is complicated and the condition is elaborated, then frequently its reason is covered. By this problem is classified into four categories: visible, hidden, concealed, and submerged. ${ }^{17)}$

14) 然後成云為之巧, 致変化之技, 題問自斯而立, 法術自斯而起。謂之両義。Some MSS 両義 is written as 両儀.

15) 於是備五技之式, 釈象形之法, 解題之精粗, 分術之邪正, 悉挙其変而以尽数学始終之道也。是故緅総 括一篇, 弁諸巻首, 誌編次之大意, 以迪来者云。

16) 題者, 署象形云為之辞, 而問所蔵之数也。是故, 辞者, 題之用而有正変之義矣。

17) 顕本具数而言者, 正辞也; 致衆技而言者, 変辞也。若所言混雑而巧辞, 則屡蔽其理。是以見、隱、伏、 潜之四題分焉。 
That being so, numbers can be used to express the condition and to give proof to the answer. If the numbers are not appropriate and the condition is not stated [properly], then there are some troubles in the reason of procedure and in answer numbers. ${ }^{18)}$

The procedure is to describe the technique of finding [answer] numbers. In its description, always there are formula, some of which cannot be changed and some can. The rule and the procedure are to find the numbers which are not stated in the problem to solve. Therefore, whenever we state a problem and seek the answer, we should observe the reason of action and perform its technique. ${ }^{19)}$

That is, if the difference is given, apply the addition; if the sum is given, apply the subtraction; if the product is given, apply the extraction of the root; if the quotient is given, apply the multiplication. In every case, we recover the original status. If the sum is questioned, apply the addition; if the difference is questioned, apply the subtraction; if the product is questioned, apply the multiplication; if the quotient is questioned, apply the division. In every case, we are convenient in finding the answer. These two situations are all based on the natural reason. ${ }^{20)}$

Certainly, the reason is hidden, clarified, general, or stuffed; the technique is slow, fast, former, or later. Hence, we classify all procedure involved into four categories: real, forcible, biased, and wrong. Therefore, we raise below 87 problems and completely discuss the meaning of loss and gain to demonstrate the norm to state the problem and to apply the procedure. $^{21)}$

\section{References}

1. Kawahara Hideki, History of Mathematics in Korea(in Japanese), University of Tokyo Press, 2010.

2. Komatsu Hikosaburo, "Report of the present status of a revision of the Taisei Sankei" (in Japanese), RIMS Kokyuroku 1546(2007), pp. 140-156.

3. Japan Academy, History of Mathematics before the Meiji Restoration(in Japanese), Volume 2, Iwanami Shoten, 1956

18) 然而数能成辞之用, 亦為答之証。若数不応, 辞不称, 則有術理答数之煩, 是以八条之病生焉。

19) 術者、述求数之技也。其所為, 常以有定式。応変之異者, 曰法, 日術, 皆求題中不言之数。故毎設題下 問, 必察当為之理而成其技矣。

20) 乃言差者, 加之; 言和者, 減之; 言積者, 開除之; 言商者, 因乗之。各復于其旧也。若問和者, 加之; 問差者, 減之; 問積者, 因乗之; 問商者, 開除之。各応于其求也。是皆自然之理也。

21) 蓋理有隱、顕、通、塞。技有遅、速、先、後。是以諸術之所起, 有実、有権、有偏、有邪。是故, 今下八十 七問, 悉論得失取捨之義而以為設題施術之軌範矣。 
4. Morimoto Mitsuo and Ogawa Tsukane, "The Mathematics of Takebe Katahiro: His Three Formulas of an Inverse Trigonometric Function," SUGAKU EXPOSITIONS, Volume 20(2)(2007), pp. 237-252. (original paper in Japanese, Sugaku 56(3) (2004), pp. 308319.)

5. Morimoto Mitsuo and Ogawa Tsukane, "Mathematics Treatise on the Technique of Linkage: An Annotated English Translation of Takebe Katahiro's Tetsujutsu Sankei preserved in the National Archives of Japan," SCIAMVS, Volume 13(2012), pp. 157-286.

6. Morimoto Mitsuo, The Suanxue Qimeng and its Influence on Japanese Mathematics, To appear in the Proceedings of the International Conference on History of Mathematics in Memory of Seki Takakazu (1642?-1708), 2008.

7. Morimoto Mitsuo, Mathematical Philosophy of Takebe Katahiro, International Conference on the History of Modern Mathematics, August 11-17, 2010, Xi'an, China. This paper will appear in RIMS Kokyuroku.

8. Study Group for History of Mathematics in East Asian, Great Collection of wasan books in Seki school: Seki San Shidensho (in Japanese), Bensei Shuppan, 2010.

\section{Morimoto Mitsuo}

Seki Kowa Institute of Mathematics, Yokkaichi University, 512-8512 JAPAN

E-mail: morimoto@yokkaichi-u.ac.jp 


\section{ABSTRACTS}

LeE Chang Koo, Hong Sung Sa 이창구, 홍성사 Chinese Mathematics in Chosun 『朝 鮮과 中國 數學』

중국 수학을 토대로 조선 수학이 발전된 것은 잘 알려져 있다. 이 논문에서는 조선에 유입된 중국 산서의 역사를 조사하여 중국 수학이 조선 수학에 끼친 영향을 연구한다. 15 세기 世눅대에 들어온 중국 수학, 17 세기 서양 수학의 영향을 받은 중국 수학과 19세기 중국에서 재정리된 송, 원대의 수학으로 나누어 이들이 유입되는 과정도 함께 조사한다.

\section{Morimoto Mitsuo Three Authors of the Taisei Sankei}

The Taisei Sankei(大成算経 in Japanese) or the Dacheng Suanjing(in Chinese) is a book of mathematics written by Seki Takakazu 関孝和, Takebe Kataakira 建部賢明 and Takebe Katahiro 建部賢弘. The title can be rendered into English as the Great Accomplishment of Mathematics. This book can be considered as one of the main achievements of the Japanese traditional mathematics, wasan, of the early 18th century. The compilation took 28 years, started in 1683 and completed in 1711. The aim of the book was to expose systematically all the mathematics known to them together with their own mathematics. It is a monumental book of wasan of the Edo Period (1603-1868). The book is of 20 volumes with front matter called Introduction and altogether has about 900 sheets. It was written in classical Chinese, which was a formal and academic language in feudal Japan. In this lecture we would like to introduce the wasan as expressed in the Taisei Sankei and three authors of the book. The plan of the paper is as follows: first, the Japanese mathematics in the Edo Period was stemmed from Chinese mathematics, e.g., the Introduction to Mathematics (1299); second, three eminent mathematicians were named as the authors of the Taisei Sankei according to the Biography of the Takebe Family; third, contents of the book showed the variety of mathematics which they considered important; fourth, the book was not printed but several manuscripts have been made and conserved in Japanese libraries; and finally, we show a tentative translation of parts of the text into English to show the organization of the encyclopedic book.

KIM Daniel G., KIM Sung Sook 김계환, 김성숙 $\quad$ The Rebirth of the IMU and ICM ${ }^{\circledR} \mathrm{IMU}$ 의 재탄생과 $\mathrm{ICM}_{\Perp}$

20 세기 초에 발생하였던 제 1,2 차 세계대전들은 유럽 사회뿐만 아니라, 수학계에도 지대한 손실을 끼쳤다. 1 차 세계대전 이후 프랑스를 중심으로 탄생되었던 국제 수학연맹 (IMU) 은 정치적으로 이용 되었던 이유로 해체되어졌고, 제 2차 세계대전이 발생함에 따라 모든 국제 학회모임은 중단되었다. 독일에 나치정권이 들어선 후, 많은 뛰어난 수학자들이 수용소에서 죽음을 맞거나 미국으로 이주하면서 학문의 중심은 유럽에서 미국으로 이동하였다. 전쟁이 끝난 후 심각한 정치 경제 위기에 처한 유럽의 